\title{
Correction to: Efficacy of a low-FODMAP diet in adult irritable bowel syndrome: a systematic review and meta-analysis
}

\author{
Anne-Sophie van Lanen ${ }^{1,2}$ (1) Angelika de Bree $^{2} \cdot$ Arno Greyling $^{2}$ (1)
}

Published online: 28 June 2021

(c) The Author(s) 2021

\section{Correction to: European Journal of Nutrition https://doi.org/10.1007/s00394-020-02473-0}

The original version of this article unfortunately contained a mistake. The $\mathrm{X}$-axis labels ('Favours [control]' and 'Favours [experimental]') were presented in the wrong order in Fig. 4.

The corrected Fig. 4 is given below.

\begin{tabular}{|c|c|c|c|c|c|c|c|}
\hline \multirow[b]{2}{*}{ Study } & \multicolumn{2}{|c|}{ LFD } & \multicolumn{5}{|c|}{ Control } \\
\hline & Mean & SD & $\mathrm{n}$ & Mean & SD & $\mathrm{n}$ & Weight \\
\hline Eswaran 2017 & 69.3 & 13.7 & 45 & 59.4 & 12.05 & 39 & $18.3 \%$ \\
\hline Harvie 2017 & 81 & 14 & 23 & 73 & 13 & 27 & $12.3 \%$ \\
\hline Paduano 2019 & 83 & 14 & 34 & 81 & 11 & 28 & $15.9 \%$ \\
\hline Pedersen 2014 & 8 & 18 & 42 & 0.1 & 15 & 40 & $13.2 \%$ \\
\hline Staudacher 2017 & 72.4 & 19.7 & 51 & 70.6 & 18.1 & 53 & $12.9 \%$ \\
\hline Zahedi 2018 & 7.3 & 8.78 & 50 & 5.35 & 9.19 & 51 & $27.4 \%$ \\
\hline Total $(95 \% \mathrm{Cl})$ & & & 245 & & & 238 & 100.0 \\
\hline
\end{tabular}

Fig. 4 Forest plot showing mean IBS-QoL values

The original article can be found online at https://doi.org/10.1007/ s00394-020-02473-0.

Anne-Sophie van Lanen

anne-sophie.vanlanen@wur.nl

1 Division of Human Nutrition and Health, Wageningen University and Research, Wageningen, The Netherlands

2 Unilever, Unilever Foods Innovation Centre, Bronland 14, 6708 WH Wageningen, The Netherlands
Open Access This article is licensed under a Creative Commons Attribution 4.0 International License, which permits use, sharing, adaptation, distribution and reproduction in any medium or format, as long as you give appropriate credit to the original author(s) and the source, provide a link to the Creative Commons licence, and indicate if changes were made. The images or other third party material in this article are included in the article's Creative Commons licence, unless indicated otherwise in a credit line to the material. If material is not included in the article's Creative Commons licence and your intended use is not permitted by statutory regulation or exceeds the permitted use, you will need to obtain permission directly from the copyright holder. To view a copy of this licence, visit http://creativecommons.org/licenses/by/4.0/.

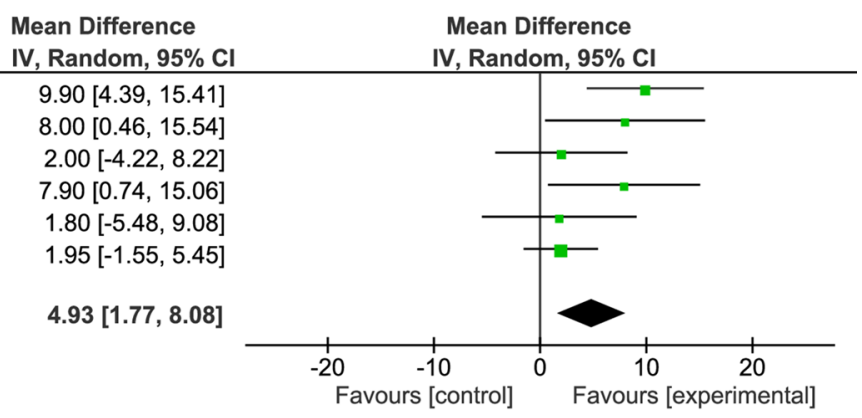

Mean Difference Mean Difference

$8.00[0.46,15.54]$

$2.00[-4.22,8.22]$

$7.90[0.74,15.06]$

$80[-5.48,9.08]$

Favours [control] 